\title{
PAMIECĆ O WOJNIE, WOJNA O PAMIĘĆ. PAMIĘĆ SPOLECZNA O WOJNIE W ALGIERII W RELACJACH POMIĘDZY FRANCJA A IMIGRANTAMI ALGIERSKIMI
}

\author{
„WOJNA W ALGIERII TRWA NADAL"
}

W ojna o niepodległość Algierii, od której zakończenia mija w tym roku 50 lat, to jedna z głównych przyczyn problemów integracji różnych grup etnicznych we Francji. Problem ten dotyczy nie tyle Algierczyków, którzy w czasie konfliktu lub niedługo po nim postanowili zamieszkać na dłuższy okres we Francji, ile ich dzieci i wnuków, czyli obywateli francuskich i absolwentów francuskich szkół, społecznie i kulturowo przynależących do społeczeństwa francuskiego (por. Camilleri 1990: 205). Odczuwają oni bardziej niż inne grupy imigranckie poczucie dyskryminacji i uważani są - przez łączony z nimi stereotyp "młodych z przedmieść" - za jeden z głównych problemów współczesnej Francji (Attias-Donfut, Wolff 2009: 269). Wojna w Algierii, a przynajmniej batalia o kształt społecznej i państwowej pamięci o tej wojnie trwa nadal - w tym duchu wypowiadają się coraz częściej i coraz odważniej socjologowie i historycy (Stora 2008; Blanchard, Veyrat-Masson 2009). Pamięć o wydarzeniach tej wojny jest dziś bardziej obecna $w$ dyskursie publicznym we Francji niż w latach 60., 70. i 80. XX wieku, kiedy była tematem tabu. Jest ona - jak często bywa w innych społeczeństwach nieradzących sobie z trudną przeszłością - wykorzystywana jako argument w bieżącej dyskusji politycznej, głównie o skuteczności francuskiego modelu integracji. Potomkowie imigrantów algierskich, podobnie zresztą jak i inni młodzi Francuzi, którzy wojnę o niepodległość Algierii znają jedynie z relacji rodzinnych i - od niedawna - medialnych i naukowych, w pewnym sensie stali się zakładnikami
Mgr Jacek KUBERA jest doktorantem w Zakładzie Socjologii Narodu i Stosunków Etnicznych w Instytucie Socjologii UAM. j.kubera@amu.edu.pl

Mgr Łukasz SKOCZYLAS jest doktorantem w Zakładzie Socjologii Kultury i Cywilizacji Współczesnej w Instytucie Socjologii UAM. luke@amu.edu.pl 
tej wojny, zostali zmuszeni do ustosunkowania się do niej. Pamięć rodzinna o konflikcie algierskim, zarówno w rodzinach algierskich, jak i rdzennie francuskich, jest w ten sposób konfrontowana z konstruowaną dopiero pamięcią szerszej zbiorowości - całego społeczeństwa francuskiego. Tworzenie pamięci społecznej Francuzów o wojnie w Algierii przebiega $\mathrm{w}$ procesie negocjowania pamięci rodzinnych i ideologii państwowej lat 60., odwołującym się do kolejnych publikacji, pojawiania się nowych filmów fabularnych i dokumentalnych, odkrywania w archiwach nowych dokumentów itd., a także do tego, jak przeszłość kolonialna Francji interpretowana jest przez polityków, zwłaszcza w okresie wyborów parlamentarnych czy - przypadających na rok 2012 - prezydenckich.

Inaczej niż w przypadku drugiej wojny światowej i formalnego rozliczenia się Francji z okresu Vichy, wojna w Algierii i towarzyszące jej przestępstwa, takie jak stosowanie tortur przez wojsko, nadal pozostają kwestią pozbawioną jednoznacznej oceny najwyższych władz państwowych. Pomimo braku tego typu oficjalnego przyznania się do dawnych błędów, pamięć w społeczeństwie francuskim o wojnie w Algierii była jednak i jest żywa, przede wszystkim dzięki wchodzącym w jego skład czterem wielkim zbiorowościom, liczącym w sumie od sześciu do siedmiu milionów osób (Stora 2008: 75). Zbiorowości te obejmują:

1) Francuzów urodzonych w Algierii, „repatriantów”, którzy osiedlili się we Francji po 1962 roku (tzw. les pieds-noirs - „czarne stopy"),

2) muzułmanów współpracujących z armią francuską, którzy po 1962 roku także zamieszkali we Francji (tzw. les harkis, od arabskiego słowa oznaczającego ruch polityczny),

3) imigrantów algierskich i ich potomków mieszkających we Francji,

4) żołnierzy francuskich, w tym dawnych młodych poborowych, uczestniczących w walkach w Algierii (na temat ich wspomnień wojennych por. Bantigny 2007).

Ponadto $\mathrm{w}$ proces tworzenia pamięci społecznej o tych wydarzeniach zaangażowani są ówcześni mieszkańcy obszaru metropolitalnego - tak Francuzi, jak i liczni już w latach 50. i 60. Algierczycy, którzy wyemigrowali do Francji w okresie jej intensywnego rozwoju gospodarczego i którzy, zgodnie z prawem z 1946 roku, posiadają status obywateli francuskich. Pamiętają oni wydarzenia w Algierii z doniesień mediów francuskich, toczonych wówczas rodzinnych i towarzyskich debat, atmosfery napięcia podtrzymywanej przez zamachy bombowe na funkcjonariuszy policji i francuskie komisariaty oraz coraz bardziej zauważalnej w tym czasie obecności policji na ulicach francuskich miast (Viet 2002: 183-192).

Pamięć, która wcześniej była indywidualna, rodzinna, po 2000 roku stała się domeną publiczną, publicznie konstruowaną i dyskutowaną. Wymienione wcześniej cztery zbiorowości najbardziej związane z tym konfliktem - z których każda ma inne doświadczenie okresu 1954-1962 i lat późniejszych, i stąd także inne jego interpretacje - stały się, po pierwsze, przedmiotami wzmożonego zainteresowania opinii publicznej, po drugie, obiektami podlegającymi ocenie różnych grup społecznych, po trzecie (co chyba najbardziej znamienne), uczestnikami tych debat, których głos - po okresie braku zainteresowania - stał się styszalny, brany pod uwagę, oraz - w konsekwencji, po czwarte - argumentem wykorzystywanym w obecnie toczonych dyskusjach.

Jedną z tych zbiorowości stanowią właśnie imigranci algierscy, ich dzieci i wnuki. Dyskutuje się o nich, o ich problemach i o ich obecności w społeczeństwie francuskim, w kontekście wojny w Algierii i przeszłości kolonialnej Francji. W tym właśnie sensie, wojna w Algierii trwa nadal: członków tego samego, jednego społeczeństwa francuskiego, obywateli tego samego państwa, dzieli ona na obozy odtwarzając stary podział na "koloni- 
zujących" i "kolonizowanych", na - znajdujących się po obu stronach tej do dziś budowanej barykady - oprawców i ofiary, budzi chęć rewanżu, dla jednych, za okres kolonialnej dominacji i dawnego wyzysku, dla drugich, za upadek imperium kolonialnego i za wygraną w wojnie, która - jak każda wojenna przegrana - była dla Francji politycznym upokorzeniem. Zarówno obecne podziały polityczne (lewica - prawica), klasowe i ekonomiczne (mieszczanie - robotnicy), jak i nierówności społeczne (mieszkańcy miast - mieszkańcy przedmieść, potomkowie imigrantów - „prawdziwi Francuzi”) tłumaczone są - często bezwiednie, nieświadomie - kontekstem dawnych podziałów, są na nie sztucznie, bo arbitralnie, nakładane. W konsekwencji przyczynia się do utrwalenie mitu (narodzonego w latach 20. i 30., a utrwalonego w latach 70., w dobie ujawnienia się kryzysu ekonomicznego i mniejszego zapotrzebowania na siłę roboczą) niedających się zasymilować Algierczyków i szerzej - Arabów, imigrantów z byłych kolonii, muzułmanów, strach przed którymi uosabiają we francuskim imaginarium właśnie Algierczycy (Belaskri 2007: 15-17). Zapomina się przy tym, że podobnie trudno przebiegała integracja innych grup migrantów (które jednak przybywały z krajów o podobnym statusie, a nie z terytoriów politycznie podległych), dziś niesłusznie uznawanych we Francji za „wzorcowe”: Polaków, Portugalczyków, Włochów (Chavanon 2001; Liauzu 2005: 107). Słowem, wojna w Algierii, "na siłę odgrzewana" - zdaniem jednych (por. Bruckner 2006) lub dziwnie zapomniana - w opinii drugich (Stora 2008), znajduje się dziś na osi konfliktu pomiędzy "rodowitymi" Francuzami a Francuzami, których rodzice lub dziadkowie byli Algierczykami.

Wzajemna niechęć, brak zaufania, postrzeganie się nawzajem we wrogi sposób oraz obecny po obu stronach jawny lub ukryty rasizm, towarzyszące imigrantom algierskim i rdzennym Francuzom mieszkającym w metropolii, nie zniknęły po zawarciu rozejmu. Wręcz przeciwnie, kultywowane w rodzinnych relacjach i wobec towarzyszącego im wcześniej oficjalnego milczenia, ukazały swą aktualność w latach 80. Czynnikiem, który spowodował eskalację zadawnionego sporu był sukces wyborczy Frontu Narodowego Jean-Marie Le Pena (notabene, byłego żołnierza walczącego w wojnie algierskiej). Później konflikt ten okazał się równie silny w latach 2000., gdy Le Pen dostał się do drugiej tury wyborów prezydenckich i gdy po 11 września 2001 roku wzrosła w społeczeństwach zachodnich islamo- i arabofobia. Dziś, gdy pojawiają się kolejne prace naukowe i udostępniane są kolejne dokumenty przedstawiające wydarzenia lat 1954-1962, te negatywne emocje, zrodzone w czasie wojny, wyraźnie podkreślające podział na "my" i "oni", jawią się jako ciągle we Francji aktualne", jakby „odziedziczone” po rodzicach i dziadkach wówczas skonfliktowanych stron (Attias-Donfut, Wolff 2009: 269-276).

1 Wojna w Algierii z okresu 1954-1962 jest dziś wyzwaniem dla społecznej pamięci po obu brzegach Morza Śródziemnego, nie tylko w Heksagonie, jak o swoim kraju - ze względu na jego kształt na mapie geograficznej - mówią Francuzi. O ile we Francji, której poświęcony jest ten artykuł, głównym problemem było, do niedawna, społeczne milczenie o wojnie z lat 1954-1962, to w Algierii stał się on tematem dominującym - legitymacją do sprawowania autorytarnej władzy przez nacjonalistów i argumentem w ich walce z wewnętrzną opozycją. Pamięć społeczna o wojnie jest w Algierii bardzo silna, jednak cząstkowa, oparta na stereotypach, legendach, i pomijająca wkład wszystkich algierskich obozów politycznych sprzed 1954 r. także tych znajdujących się na emigracji, w uzyskanie niepodległości. „Dziury w pamięci” czy „obszary zapomnienia", jak określa to historyk Benjamin Stora, dotyczą więc także strony algierskiej, gdzie - w oficjalnej wykładni - próbuje ukryć się, że wojna odbywała się nie tylko pomiędzy nacjonalistami algierskimi i żołnierzami armii francuskiej (rozgrywanym wewnątrz ówczesnego Państwa Francuskiego, tak na terenie jego departamentów algierskich, jak i francuskich), ale że równolegle miały miejsce dwie innego rodzaju wojny domowe: pomiędzy Algierczykami i pomiędzy Francuzami mającymi zróżnicowane, skonfliktowane wizje przyszłości Algierii. W oficjalnej wykładni w Algierii, która swą tożsamość polityczną oparła na pamięci o wojnie i na wzmocnieniu prestiżu instytucji religijnych i wojskowych, brakuje także konstatacji, że ostatecznie Algierczycy wygrali tę wojnę nie tyle za sprawą działań militarnych, ale dzięki zabiegom politycznym i politycznej atmosferze sprzyjającej wówczas w świecie aspiracjom niepodległościowym byłych kolonii brytyjskich czy francuskich (por. Stora 2008: 74-77). 
W kolejnych częściach tego artykułu zaprezentujemy odmienne strategie konstruowania pamięci społecznej o wojnie w Algierii. Pierwsza z tych strategii dotyczy pamięci oficjalnej, publicznej, kreowanej przez władze państwowe i przez środki przekazu trafiające do szerokiego grona odbiorców. Druga zaś jest strategią odnoszącą się do pamięci nieobecnej w oficjalnym i masowym przekazie, do pamięci rodzinnej i pamięci wspólnoty etnicznej stanowiącej mniejszość $w$ danym społeczeństwie.

\section{POLITYKA NIEPAMIĘCI PAŃSTWA FRANCUSKIEGO}

Wojna algierska pozostawiła we Francji kilka problemów, wobec których zarówno większość społeczeństwa jak i władze państwowe zastosowały politykę milczenia, usuwając pewne tematy z dyskursu publicznego, chcąc jak najszybciej o tej wojnie i o jej skutkach zapomnieć. Nawet jeśli były one osnową dla niektórych prac naukowych, nie interesowały się nimi najważniejsze media aż do 2000 roku, kiedy Raphaëlle Branche, po uprzednim otwarciu archiwów wojskowych w 1992 roku, obroniła doktorat omawiający stosowanie tortur przez wojsko w czasie wojny w Algierii i ukrywanie tego faktu przez Francję (Thénault 2004). Podobnie było z pracami o charakterze innym niż naukowy, np. z filmami poświęconym okresowi 1954-1962. Nawet obraz włoskiego reżysera Gillo Pontecorvo Battaglia di Algeri („Bitwa o Algier”), nagrodzony w 1966 roku Złotym Lwem na festiwalu w Wenecji, pomimo popularności wśród pokolenia ‘68, które w latach 70. film mogło obejrzeć w wybranych salach Dzielnicy Łacińskiej, czekał aż do października 2004 roku na wyemitowanie we francuskiej telewizji (Stora 2008: 69-70).

Pierwszym problemem, o którym próbowano zapomnieć, był sam udział w wojnie, którą za wojnę uznano oficjalnie dopiero w latach 90., wcześniej nazywając ją "wydarzeniami w Algierii" czy "rebelią algierską". Do dziś wielu historyków kwestionuje zasadność nazywania Algierii „,kolonią” (zob. Monneret 2008: 11-12 i 48), tłumacząc, że w przeciwieństwie do innych nieeuropejskich terytoriów zależnych od Francji, Algieria była integralną częścią Państwa Francuskiego, z departamentami o takim samym statusie, jak te znajdujące się w Alzacji czy Bretanii. Stąd, ich zdaniem, Francja nie mogła prowadzić wojny sama przeciwko sobie. Wojnę w Algierii przez długi okres traktowano jako wewnętrzny konflikt z rebeliantami, którzy nie reprezentowali interesów wszystkich mieszkańców algierskich departamentów (tak było $w$ istocie, bo Algierczycy byli politycznie podzieleni, prowadząc również między sobą walki po obu stronach Morza Śródziemnego, które przyczyniły się do śmierci od czterech do dziesięciu tysięcy ludzi [Viet 2002: 184]). Z tych też powodów nie mówi się o tym konflikcie jako „wojnie algiersko-francuskiej”. Trudno zatem było nazwać traumy wojny w Algierii, skoro samym „wydarzeniom” odmawiano rangi konfliktu wojennego. Traumy te pozostały niezwerbalizowane nie tylko na poziomie indywidualnym, dotycząc żołnierzy bezpośrednio w walkach uczestniczących (Bantigny 2007), ale także na poziomie całego społeczeństwa, pozostawiając uczucie wstydu, Freudowskie zranienie narcystyczne (por. Liauzu 2005: 106). Zranienie to wynika z udziału w wojnie, która, jak twierdził psychoanalityk, "odrzuca wszystkie ograniczenia, którym poddajemy się w czasie pokoju i które zwiemy prawem ludzkim" (cyt. za: Stora 2008: 73, tłum. własne). Wobec traumatycznych przeżyć zapomnienie, Freudowska potrzeba wyparcia, może więc pełnić dla społeczeństwa rolę pozytywną, jest czymś naturalnym, służącym odbudowaniu tożsamości (Stora 2008: 101). Ważna przy tym pozostaje praca historyków, których 
zadaniem jest przekazanie wiedzy o wydarzeniach przyszłym pokoleniom i unikanie takiego pisania historii, które wzniecałoby nienawiść do dawnych wrogów. Benjamin Stora (2008: 102-103) odróżnia jednak takie „prawowite, konieczne, ewidentne zapomnienie” pozwalające normalnie funkcjonować społeczeństwu od „zapomnienia zorganizowanego przez państwo", którego celem jest uniknięcie odpowiedzialności przez pewnych ludzi czy przez całe grupy społeczne. Jest to dla niego zapomnienie perwersyjne (etymologicznie: „odwrócone”), odgórnie zorganizowane, utrudniające prace historykom. Stora (2008: 102) twierdzi też, że te dwa typy mogą wzajemnie na siebie wpływać i czerpać z siebie nawzajem oparcie. Wydaje się, że tak jest właśnie w przypadku unikania słowa „wojna": wpisane w cały szereg działań politycznych (poświęcamy im następne akapity), które z jednej strony pozwalały społeczeństwu francuskiemu, przynajmniej przez pewien czas, zapomnieć o wojennej traumie, z drugiej zaś - stanowiły przeszkodę dla badania okresu tej wojny, tak przez historyków, jak i przez wymiar sprawiedliwości.

Drugi problem stanowił przyjazd do Francji w bardzo krótkim okresie po wojnie kilku milionów osób reprezentujących przede wszystkim trzy z czterech wcześniej wymienionych zbiorowości (oprócz imigrantów, których obecność od lat 50. była w Heksagonie permanentna) bezpośrednio zaangażowanych w konflikt rozgrywający się na terenie Algierii. Ówczesnym władzom zależało na tym, aby jak najszybciej zostali oni - żołnierze, harkis oraz repatrianci - włączeni do społeczeństwa metropolitalnego bez konieczności rozdrapywania świeżych ran czy moralnego, a tym bardziej jurysdykcyjnego, osądzania ich poczynań w czasie wojny, podczas której reprezentowali przecież francuską stronę. Przypomnijmy, że we Francji wiele osób uważało za swój patriotyczny obowiązek wyrażenie potępienia wobec popierających dążenia niepodległościowe Algierii Francuzów i Algierczyków (co z góry rzucało cień podejrzeń na mieszkających we Francji imigrantów algierskich) oraz czynienie wobec nich aluzji do kolaborantów z okresu rządu Vichy. Z kolei, zwłaszcza w kręgach lewicowych, za takich kolaborantów walczących w złej sprawie uważano harkis, czyli Algierczyków, którzy współpracowali z armią i z policją francuską (notabene, łatwość, z jaką posługiwano się etykietą kolaborantów z nazistami, pokazuje, że przez długi czas, aż do lat 90., niejednoznaczny udział Francuzów w drugiej wojnie światowej także pozostawał pod osłoną polityki zapomnienia). To właśnie harkis, którym Francja za pomoc w czasie wojny obiecywała bardzo wiele, zmuszeni do opuszczenia Algierii i zamieszkania w zupełnie sobie nieznanym kraju dawnego kolonizatora, spotykali się często z aktami przemocy, odrzuceniem i pogardą mieszkańców metropolii. Podobnie wyglądało przyjęcie Europejczyków mieszkających często od pokoleń w Algierii: nie znajdowali oni akceptacji wśród Francuzów, którzy w kończącym konflikt referendum opowiedzieli się za samostanowieniem Algierii i nie zawsze chcieli przyjmować na siebie ciężar dekolonizacji (Stora 2008: 75). Co prawda, pieds-noirs nie dotykał bynajmniej rasizm antyarabski, tak jak w przypadku harkis, gdyż wyglądem nie różnili się od innych Europejczyków, jednak ich dawne miejsce zamieszkania (widoczne do dziś w numerach ubezpieczenia społecznego INSEE, w których wskazane są nieistniejące już departamenty algierskie) wciąż jest przez wielu z nich z przezorności ukrywane. Kojarzą się z „kolonizatorami” i zapewne niejeden z nich usłyszał to, co głosiły napisy w porcie Marsylii zaraz po ich przypłynięciu do francuskiego brzegu: „Pieds-noirs, wracajcie do siebie” (por. Stora 2008: 75). Ponadto, ambiwalentny stosunek społeczeństwo francuskie przejawiało również w stosunku do armii francuskiej walczącej w Algierii.

Rozwiązaniem problemu obecności byłych żołnierzy, harkis i byłych „kolonizatorów” miała być seria amnestii, z których pierwszą wprowadzono nazajutrz po zakończeniu 
wojny, w 1962 roku; później ogłaszano je w latach 1964, 1968 i 1974 (Stora 2008: 120). Dawały one wolność osobom związanym z wojną w Algierii, ale także odpowiedzialnym za wydarzenia rozgrywające się na jej tle we Francji, takie jak tzw. masakra paryska² z 17 października 1961 roku. Dekrety te zabraniają domagania się sprawiedliwości przed sądami przez ofiary wojny w Algierii. W przeciwieństwie do zbrodni popełnionych za reżimu Vichy, przestępstwa tego okresu nie są uznane za zbrodnie przeciwko ludzkości lub za zbrodnie wojenne, co powoduje, że żaden z ich sprawców nie będzie postawiony przed trybunatem francuskim. Z kolei prawo podpisane w 1982 roku przez François Mitterranda pozwoliło nawet na rehabilitację wcześniej skazanych czterech generałów, którzy w kwietniu 1961 roku zorganizowali pucz przeciwko de Gaulle'owi w obronie Algierii francuskiej (Stora 2007: 18; Stora 2008: 120). Sytuacja ta, uniemożliwiająca wyjaśnienie wielu spraw przede wszystkim mniejszości algierskiej we Francji, stwarza też paradoksy. Przykładowo, generał Paul Aussaresses nie został skazany przez sąd francuski za dokonywanie aktów torturowania, do których przyznaje się w swoich publikacjach, ale za to, że dokonuje w tych tekstach apologii zbrodni wojennych (Stora 2007: 18).

Trzecim problemem, ściśle związanym z obecnością imigrantów algierskich we Francji, była i jest utracona po wojnie imperialna wielkość Państwa Francuskiego. Historia kolonializmu zniknęła po 1962 roku z podręczników szkolnych, co utrudniało dostęp do wiedzy nie tylko o dawnej, utraconej potędze, ale i o nadużyciach tego okresu i nierównościach wpisanych w system kolonialny. Wynikało to z niepisanego porozumienia politycznego o potrzebie dekolonizacji i konieczności wyciszenia nostalgii za francuską Algierią (choć konsensusu nie zaakceptowała skrajna prawica, od lat 80. reprezentowana przez Front Narodowy). Francja odtąd miała zapomnieć o Południu i zaangażować się w konstruowanie zjednoczonej Europy (Stora 2008: 120). Pewnym zwrotem w polityce francuskiej kształtowanej przez to obowiązujące przez prawie trzydzieści lat ustalenie była zgoda na otwarcie, dotychczas historykom niedostępnych, archiwów wojskowych w 1992 roku. Przyczyniło się to do opublikowania pod koniec lat 90. i w roku 2000 kilku ważnych prac 3 na temat okresu kolonialnego i samej wojny algierskiej, co szybko uczyniło kwestie przeszłości kolonialnej przedmiotem publicznej, zmediatyzowanej, debaty. Od tego czasu dawne resentymenty i antyimigranckie hasła zaczęły być ważnym argumentem w aktualnym sporze politycznym, przynosząc głosy wyborcze takim politykom jak Jean Marie Le Pen (drugie miejsce i 16,86\% w pierwszej turze wyborów prezydenckich w 2002 roku [Bilan du... 2002]), Nicolas Sarkozy (wygrana w wyborach 2007 roku, w czasie których jawił się jako zwolennik twardej polityki wobec imigrantów), czy obecnie Marine Le Pen

Chodzi o pokojową, choć zakazaną, manifestację Algierczyków mieszkających w Paryżu i w regionie paryskim, którzy odpowiadając na apel Frontu Wyzwolenia Narodowego (Front de Libération Nationale), wyszli na ulice Paryża w proteście przeciw wprowadzeniu w mieście godziny policyjnej mającej obowiązywać tylko mniejszość algierską. Manifestacja, która odbyła się w ostatniej fazie wojny, po zerwaniu wstępnych negocjacji o rozejmie, spotkała się z atakiem służb porządkowych i policji (motywem mógł być strach lub chęć zemsty za wcześniej dokonywane przez FWN zamachy bombowe). W różny sposób (strzelanie na ślepo z broni palnej, zrzucanie manifestantów z mostów do Sekwany, zbiorowe egzekucje w budynkach policji) zginęło wówczas kilkadziesiąt, a zdaniem niektórych badaczy od 200 do 300 osób, aresztowania objęły zaś od 10 do 15 tysięcy ludzi. Dokładne liczby strat nie zostaną już prawdopodobnie nigdy poznane z powodu zniknięcia z różnych archiwów kluczowych dokumentów (Viet 2002: 190; Chemin 2011).

3 Chodzi głównie o trzy rozprawy doktorskie napisane przez młode osoby, nie pamiętające z własnego doświadczenia wojny z lat 1954-1962, okrzyknięte w 2000 r. przez Roberta Bonnauda jako „trzy młode, nieustraszone i uparte kobiety" (Thénault 2004: 193): Appelés en Algérie: la parole confisquée ("Poborowi w Algierii: skonfiskowane słowa") autorstwa Claire Mauss-Copeaux (obrona w 1998 roku, publikacja w 1999), La Torture et l'Armée pendant la guerre d'Algérie ( „Tortury i wojsko w czasie wojny w Algierii”) autorstwa Raphaëlle Branche (doktorat obroniony w 2000 roku, opublikowany w 2001), Une drôle de justice. les magistrats dans la guerre d’Algérie („Dziwna sprawiedliwość: wymiar sprawiedliwości w czasie wojny w Algierii") napisaną przez Sylvie Thénault (obrona i publikacja w 2001 roku). 
(sondaże przed wyborami w kwietniu 2012 roku dają jej trzecią lokatę i 17\% głosów [Intentions... 2012]).

Zakwestionowaniem dawnego kompromisu była również ustawa przyjęta w 2005 roku pod naciskiem stowarzyszeń repatriantów i harkis (Le Cour Grandmaison 2006: 146), o konieczności podkreślania w programach szkolnych pozytywnych aspektów francuskiej obecności w Afryce Północnej (Liauzu 2005: 99-102). Imigranci algierscy, a właściwie ich potomkowie - widoczny znak niepowodzeń starań o zachowanie imperialnej potęgi i wywołujące poczucie winy świadectwo dawnej polityki kolonialnej (Gonzalès 2007: 25) - stali się ważnym podmiotem i przedmiotem ówczesnych dyskusji. Rozpoczęte przez nich protesty po uchwaleniu ustawy, wspierane przez francuską i zagraniczną prasę i oprotestowane przez francuskie Stowarzyszenie Nauczycieli Historii i Geografii (Liauzu 2005: 101 i 106), doprowadziły do wykreślenia z niej kontrowersyjnego zapisu. Z kolei, wcześniej, w obronie dobrego imienia armii francuskiej wystąpiły środowiska kombatantów, repatriantów, harkis oraz dawni zwolennicy Algierii francuskiej. Głównie z powodu nacisków z ich strony zdecydowano się na ponowne zamknięcie archiwów wojskowych w 2002 roku.

Rozpoczęta około 2000 roku debata ukazała drzemiące w zbiorowościach znajdujących się niegdyś po przeciwnych stronach wojennej barykady wzajemne resentymenty, poczucie krzywdy i potrzebę jej, choćby symbolicznego, wynagrodzenia. Choć archiwa wojskowe są znów zamknięte, a kolonializmem francuskim ciągle zajmują się częściej Amerykanie, Brytyjczycy czy Japończycy niż sami Francuzi (we Francji nie ma nawet żadnej jednostki naukowej w randze katedry zajmującej się tym problemem [Stora 2007: 30]), wydaje się, że szanse na wyciszenie nastrojów, nie mówiąc już o integracji skłóconych grup etnicznych, są obecnie niewielkie. Rację ma w tym przypadku B. Stora (2008: 103), kiedy twierdzi, że „amnezja może funkcjonować jak bomba z opóźnionym zapłonem. Jeśli żądze nienawiści i żale pozostają zbyt długo zamknięte w przestrzeni prywatnej, istnieje ryzyko, że wybuchną w przestrzeni publicznej wiele dziesiątków lat później". Niezwykle trudno też będzie wyciszyć dążenia mniejszości algierskiej do oficjalnego potępienia kolonializmu i wykroczeń z czasu wojny 1954-1962, zwłaszcza że Państwo Francuskie, głosami parlamentarzystów, dokonało już takiej oceny w stosunku do przestępstw z okresu Vichy, a także zjawisk i wydarzeń z przeszłości, które są problemowe nie dla Francji, ale dla innych krajów: niewolnictwa, uznawanego od 2001 roku za jedną ze zbrodni przeciwko ludzkości, czy mordu Ormian w tureckiej Anatolii (Liauzu 2005: 103; Dobiecki 2012)

Polityka niepamięci o przeszłości kolonialnej i o wojnie w Algierii, jaką prowadziło Państwo Francuskie po 1962 roku, odpowiadała społecznej potrzebie jak najszybszego powrotu do normalnego funkcjonowania. Jak wspomina francuska socjolog Annie Ernaux w Les Années, „ludzie mieli już wystarczająco dość Algierii, bomb pozostawianych na parapetach przez $\mathrm{OAS}^{4}$, nieudanego zamachu na prezydenta de Gaulle'a zorganizowanego przez francuskich wojskowych, którzy nie zgadzali się z jego polityką wobec Algierii. (...) Ich pragnienie szczęścia i spokoju doskonale współgrało z zaprowadzeniem zasady sprawiedliwości - dekolonizacji, która kiedyś była nie do pomyślenia" (cyt. za: Stora 2008: 28, tłum. własne). Pamiętać należy, że jednoznaczne odniesienie się do wydarzeń sprzed 1962 roku byłoby zanegowaniem słuszności podejmowanych wówczas działań albo przez domagających się prawa do samostanowienia Algierczyków (co podważałoby także decyzję de Gaulle'a i społeczeństwa francuskiego, wyrażoną w referendum, o zakończe-

4 Organisation de l'Armée Secrète („Organizacja Tajnej Armii”) - organizacja terrorystyczna sprzeciwiająca się niepodległości Algierii. 
niu wojny), albo przez armię francuską będącą jednym z filarów tożsamości państwowej i narodowej godności, wystarczająco już osłabionej, jeśli nie poniżonej, zdaniem niektórych, po wojennej przegranej (która była drugą tak ważną niedawną porażką, jeśli brać pod uwage wynik militarnej i politycznej konfrontacji Francji z nazistowskimi Niemcami). Konsensus polegający na wyborze polityki zapomnienia wynikał zatem z konieczności odbudowy spokoju społecznego oraz zaufania wszystkich grup społecznych do instytucji państwa funkcjonującego w zupełnie nowej rzeczywistości. Z drugiej strony, polityka państwowa, która wstrzymuje się od wyraźnej oceny przeszłości, nie wskazuje wyraźnie ani bohaterów, ani antybohaterów wcześniejszych wydarzeń, ryzykuje wybuchem dawnych, niewypowiadanych w dyskursie publicznym, ale obecnych w sferze prywatnej emocji. Jak pisze Ernaux, po 1962 roku Francuzi, pomimo że chcieli zapomnieć o wojennej atmosferze, „ciągle jednak przejawiali strach, lub w najlepszym przypadku obojętność wobec "Arabów». Unikali ich, ignorowali, nie dopuszczali nigdy do sytuacji, kiedy mogliby minąć się na ulicy z tymi, których bracia dokonywali zamachów na Francuzów po drugiej stronie Morza Śródziemnego" (cyt. za: Stora 2008: 28, tłum. własne). Sytuacja, w której zrealizowane dążenia niepodległościowe mieszkańców byłej kolonii uznaje się za niesłuszne, czyni ich przedstawicieli - imigrantów - wewnętrznymi wrogami państwa. Takie wrogie postrzeganie Algierczyków wzmagał również fakt, że przez lata 60. i 70. ich obecność we Francji uznawana była za tymczasową, co z pewnością utrudniało traktowanie ich jako trwałego i zintegrowanego elementu społeczeństwa francuskiego (w latach 80. uświadomiono sobie istnienie drugiego pokolenia imigrantów algierskich).

Warto w tym kontekście zaznaczyć, że wojny o pamięć są w warunkach globalizacji czymś uniwersalnym, a nie specyficznie francuskim. Ogniskują je, według Pascala Blancharda i Isabelle Veyrat-Masson, przede wszystkim dwie kwestie: walka ofiar, które pragną społecznego uznania i oficjalnego potwierdzenia cierpień, a przy tym rywalizują między sobą, oraz poczucie winy, jakie chce się albo samemu ukryć, albo wymusić na dawnym oprawcy (Blanchard, Veyrat-Masson 2009: 44-45). Ponadto, wojna jako wydarzenie traumatyczne dla każdego społeczeństwa, zawsze będzie wywoływać ambiwalentne oceny i tworzenie - w różnych grupach - niekiedy przeciwstawnych wizji walki dobra ze złem, z których każdą należy uznać za próbę uzasadnienia strat we własnych szeregach i nadania sensu traumie. Pokazuje to także przykład ogromnych trudności, jakie towarzyszyły społeczeństwu niemieckiemu w negocjacji adekwatnej pamięci społecznej II wojny światowej, czy występujące - choć oczywiście w innej skali - również w przypadku polskiej pamięci społecznej dotyczącej tego okresu (Kwiatkowski 2010).

Jeśli chodzi o politykę zapomnienia, jest ona najczęściej realizowana na kilka sposobów. Piotr Tadeusz Kwiatkowski (2009: 107-121) wymienia cztery strategie „czynnego generowania zbiorowej niepamięci": negację, zacieranie śladów, cenzurowanie i akt sprawiedliwości. Każda z nich znalazła swoje odzwierciedlenie również we francuskiej polityce niepamięci o wojnie algierskiej. Poprzez negację Kwiatkowski rozumie zaprzeczanie samego faktu zaistnienia wydarzenia. Ta znana od lat psychologom na poziomie jednostkowym strategia wykorzystana bywa w celu odsunięcia wszelkiej odpowiedzialności od sprawców danych wydarzeń. We Francji negacja polegała na nieużywaniu słowa „wojna" i postrzeganiu jej jako konflikt wewnętrzny oraz na minimalizowaniu - do tylko trzech osób - liczby ofiar tzw. masakry paryskiej. Zacieranie śladów to kolejna strategia stosowana przeciwko pamięci, która również było stosowana w tym przypadku. To właśnie z powodu tajemniczego zniknięcia licznych dokumentów z archiwów, w tym sprawozdawczego raportu napisanego przez prefekta policji dla rządu i prezydenta, do dziś 
nie udało się ustalić ostatecznej liczby ofiar wspomnianej już masakry z 17 października 1961 roku (Viet 2002: 190). Za zacieranie śladów uważać można także podkreślanie liczby zabitych w czasie wojny francuskich żołnierzy czy Francuzów i Europejczyków z Algierii, akcentowanie brutalności ataków terrorystycznych bojówkarzy algierskich przy jednoczesnym niemówieniu o nagminnym stosowaniu przez armię francuską tortur. Ponadto, na paryskim Grobie Nieznanego Żołnierza pod Łukiem Tryumfalnym do dziś znajduje się tablica poświęcona wszystkim walczącym dla Francji podczas wojny w Algierii, która czyni bohaterami tylko jedną stronę konfliktu, ustawiając drugą w roli jedynego negatywnego aktora omawianych wydarzeń. Trzecia strategia "generowania zbiorowej niepamięci", czyli cenzurowanie, a więc - w rozróżnieniu Kwiatkowskiego - utrudnianie zdobywania wiedzy o przeszłości - realizowana była i jest (z wyjątkiem okresu 1992-2002) poprzez nieudostępnianie historykom archiwów wojskowych (działania armii w czasie wojny algierskiej) lub archiwów miejskich w Paryżu (udział policji w wydarzeniach z 17 października 1961 roku). Choć nie wydano żadnego dekretu, istniała również autocenzura lub cenzura nieoficjalna utrudniająca społeczny odbiór i obieg filmów dokumentalnych poświęconych wojnie o niepodległość Algierii. Co zaś tyczy się aktu sprawiedliwości, rozumianego jako zapominanie za karę lub w akcie wybaczenia, z pewnością zauważalny jest on w serii amnestii uniemożliwiających ściganie przestępstw wojny algierskiej.

Uniwersalne w polityce niepamięci prowadzonej przez państwa w różnych miejscach na świecie jest nie tylko podobieństwo strategii, ale również marginalizowanie mniejszości, które swą obecnością przypominają o minionych problemach ${ }^{5}$. Często nawet zaprzecza się istnieniu tych mniejszości, próbując politycznie konstruować je w oparciu o inną cechę charakterystyczną, która zmienić może sposób postrzegania członków mniejszości przez większość. Proces ten widać choćby w zdecydowanym uznawaniu za cechę charakterystyczną imigrantów ich tożsamości religijnej (rzeczywistej lub tylko domniemanej) zamiast tożsamości związanej z miejscem pochodzenia. Łączy się to z przyjętą powszechnie tezą, iż kategoria narodu jest wytworem europejskiego oświecenia i nie nadaje się do opisywania tożsamości ludzi pochodzących z innych części świata, takich jak, w przypadku Algierczyków, Afryka Północna. Przykładem takiego myślenia jest traktowanie mniejszości pochodzących z różnych miejsc jako - choć, ponownie, nie ma o tym mowy w żadnym dekrecie - jednej mniejszości muzułmańskiej. Stąd, powszechne we Francji, określanie imigrantów z Algierii, Maroka czy Tunezji i ich potomków jako „muzułmanów". Równoznaczne jest to z konstrukcją podwójnej obcości: z jednej strony, tej oficjalnie podkreślanej, religijnej, z drugiej zaś - etnicznej, pozostającej w domyśle, nieoficjalnej, obecnej w schematach postrzegania imigrantów z różnych regionów świata.

\section{PODTRZYMYWANIE PAMIĘCI PRZEZ MNIEJSZOŚĆ}

Pamięć o wojnie w Algierii, niezależnie od oficjalnej polityki w tym względzie, obecna była w rodzinach francuskich, których potrzebę zapomnienia o wojennej traumie i powrotu do normalnego funkcjonowania realizowała polityka państwa, oraz w rodzinach imigrantów algierskich (Stora 2007: 18). Jeśli chodzi o Algierczyków, podtrzymywaniu pamięci

5 Podobnie rzecz ma się z wieloma grupami ludności w ZSRR, gdzie ich obecność na danym terenie stanowi rezultat (a dzisiaj - przypomnienie) polityki przesiedleń stosowanych przez komunistyczne władze. To samo dotyczy Indian w krajach amerykańskich czy obecnej na polskim Pomorzu mniejszości ukraińskiej. Jak pisze Appadurai (2009: 48), „mniejszości przypominają też o niepowodzeniach rozmaitych projektów państwa (socjalistycznych, dewelopmentalistycznych i kapitalistycznych). Są symbolem klęski i przymusu". 
sprzyjały, wyróżniające tę mniejszość spośród innych grup imigrantów, bardzo silne więzy rodzinne. Więzi te wyrażają się w deklarowanej uległości dzieci względem opinii rodziców (w czym Algierczycy ustępują jedynie Marokańczykom) oraz w większej niż gdzie indziej (choć mniejszej niż u Tunezyjczyków i Marokańczyków) gotowości rodziców do wyrzeczeń dla dobra dzieci (Attias-Donfut, Wolff 2009: 182, 192-193). Ponadto, rodzice pochodzenia algierskiego reprezentują we Francji jeden z najwyższych wskaźników pozytywnych odpowiedzi na pytanie: „Czy jest dla ciebie ważne, aby twoje dzieci myślały tak jak ty?" (Attias-Donfut, Wolff 2009: 193-194). Pamięć Algierczyków o okresie 1954-1962, o którym społeczeństwo francuskie chciało zapomnieć, jawi się w tym kontekście jako element oporu wobec polityki władz i dominującej francuskiej kultury, który mógł znacząco wpłynąć na utrzymywanie się poczucia kulturowej odmienności wśród imigrantów. Pamięć społeczna pozwala bowiem budować tożsamość, jest jej rezerwuarem i punktem odniesienia. Warto przy tym zaznaczyć, że mówiąc dalej o podtrzymywaniu pamięci przez Algierczyków, będziemy mieli na myśli całą wspólnotę Algierczyków we Francji, nie zaś poszczególne rodziny, które mogły różnić się w ocenie zasadności przekazywania wiedzy o przeszłych wydarzeniach (nie tylko historii wojennej, ale także historii rodzinnej, w tym tej dotyczącej okresu sprzed emigracji), w sposobie i w intensywności jej komunikowania (momenty życia, w których się o tym mówi, ilość przekazywanych informacji, zróżnicowane emocje w stosunku do określonych elementów zbiorowej pamięci, sposoby celebrowania ważnych wydarzeń itd.), a także w doborze odbiorców (wszystkie dzieci czy tylko niektóre) poszczególnych treści (Fabbiano 2009).

Z pewnością stymulująco na pamięć społeczną o wojnie w Algierii wpłynęła - w sposób dość paradoksalny - wymiana pokoleniowa. Normalnym procesem wydaje się utrata części pamięci lub też złagodzenie jej ładunku emocjonalnego towarzyszące mijającym latom i procesowi wymiany pokoleń. Jednak w przypadku imigrantów kolejne pokolenia są najczęściej lepiej zintegrowane z krajem, w którym ostatecznie osiedli ich rodzice. Charakteryzują się również wyższym stopniem kompetencji kulturowej i większymi prawami politycznymi. Mają więc możliwości wprowadzania elementów pamięci społecznej swojej wspólnoty do obiegu państwowej polityki pamięci, a także - co niezwykle istotne - wiedzą, jak i nie boją się tego robić. Wydarzenia, których pamięć była dotychczas pielęgnowania w zaciszu domowym, mogą dzięki temu zaistnieć w ogólnokrajowym dyskursie publicznym. W przypadku Francji jest to szczególnie ważne, imigranci mają tam bowiem wyjątkowo niewielkie prawa polityczne - w Indeksie polityki integracji migrantów, obejmującym większość krajów Unii Europejskiej, dostępność praw wyborczych oceniono jako najniższy możliwy poziom 0\% (Niessen, Huddleston, Citron 2007: 71; por. Stankiewicz 2011). Dopiero ich potomkowie, zyskujący obywatelstwo francuskie na podstawie „prawa ziemi”, mają szansę na upolitycznienie traumatycznych wydarzeń z przeszłości.

O ile dla pierwszego pokolenia imigrantów najważniejszą kwestią była dobra praca, a dla drugiego - integracja polityczna, to trzecie pokolenie chce być we wszystkich kwestiach traktowane tak jak inni obywatele (Stora 2007: 11-12). W interesującym nas przypadku integracja imigrantów algierskich (a właściwie Francuzów pochodzenia algierskiego) z całością społeczeństwa francuskiego nie przebiega jednak bez przeszkód. Pierwszą barierą na drodze do pełnej integracji jest fakt, że Algierczycy są we Francji najsilniejszą grupą kultywującą opozycyjną, w stosunku do polityki historycznej władz, pamięć o wojnie w Algierii. Jest ona opozycyjna również wobec działań tak wpływowych grup jak repatrianci, byli żołnierze armii francuskiej i harkis, ale - z drugiej strony - jest wspierana przez niektóre lewicowe kręgi polityczne, wybrane związki zawodowe i organizacje pozarządo- 
we. Po drugie, zwłaszcza dla imigrantów należących do pierwszego pokolenia, którzy utracili już „iluzję powrotu”, obecność na ziemi francuskiej jest znakiem upadku ich własnego kraju i samej idei wojny o niepodległość, świadectwem poszukiwania ratunku u dawnych „panów”, co powoduje często deprecjację samego siebie lub negowanie własnych korzeni (Gonzales 2007: 25). Algierczycy, którzy po kilkudziesięciu latach pracy poza Algierią osiągają lub już osiągnęli wiek emerytalny, spośród wszystkich imigrantów we Francji najsłabiej wyrażają chęć przeprowadzenia się do kraju urodzenia (tylko $2 \%$ z nich tego chce), co przy ciągle żywej pamięci o wojnie sprzed 50 lat, czyni z Francji miejsce wygnania, z którego nie ma już możliwości powrotu (Attias-Donfut, Wolff 2009: 269).

Istnienie opozycyjnych „grup pamięci” (Stora 2008) ujawniła całemu społeczeństwu publiczna debata rozpoczęta około 2000 roku, w której - ku zaskoczeniu wielu komentatorów i wbrew dotychczasowej polityce mediów realizującej konsensus polityki zapomnienia - udało się imigrantom narzucić „symboliczny i polityczny podział pomiędzy samozwańczymi obrońcami wartości uniwersalnych drogich Republice a zwolennikami wartości partykularnych przedstawianych jako nieodpowiadające założeniom wpisanym w założenia funkcjonowania instytucji francuskich i francuskiej tradycji" (Le Cour Grandmaison 2006: 152, tłum. własne). Dzięki temu, że drugie i trzecie pokolenie imigrantów algierskich powołuje się dziś na takie hasła jak „wolność, równość, braterstwo”, występując w publicznej debacie jako Francuzi domagający się od państwa respektowania ich praw obywatelskich, ich argumenty mogą być traktowane jako pochodzące z wewnątrz społeczeństwa francuskiego, a nie jako głos tymczasowo obecnych (tak postrzegani byli Algierczycy do początku lat 80.), niezwiązanych kulturowo z tym społeczeństwem jednostek. Z drugiej jednak strony, takie głośne przeciwstawianie się obowiązującemu do niedawna niepisanemu porozumieniu milczenia o traumie wojny w Algierii, oficjalnie, a nie jak dawniej, w sposób zawoalowany, sytuuje dzieci i wnuków imigrantów algierskich w roli wewnętrznych wrogów Państwa Francuskiego, do której przyzwyczaili ich pewnie dziadkowie i rodzice (Attias-Donfut, Wolff 2009: 270). Co prawda Algierczycy - jedna z tych mniejszości etnicznych we Francji, które najczęściej doświadczają aktów dyskryminacji (Attias-Donfut, Wolff 2009: 79) - od wielu lat czują się postrzegani jako wrogowie, jednak dopiero usilne domaganie się przez nich zrewidowania polityki niepamięci, przywraca debacie publicznej argumenty odwołujące się do wojennych resentymentów, niegdyś przywoływane tylko przez skrajną prawicę, dziś wykorzystane, choć w różny sposób, przez polityków wszystkich opcji politycznych.

Interesujące jest, iż wieloletni brak oficjalnego rozliczenia się na poziomie władz centralnych z przestępstwami wojny algierskiej oraz próby zamazania pamięci o tym okresie, zaowocowały wytworzeniem się wspólnoty ludzi pielęgnujących tę pamięć. Być może zadziałały tu mechanizmy podobne do tych występujących w państwach o charakterze autorytarnym, których władze nie pozwalają oficjalnie kultywować pamięci o pewnych wydarzeniach, nie doprowadzając jednocześnie do całkowitego wymazania tejże. Za najbardziej oczywisty przykład może służyć sytuacja w Polsce i w innych państwach bloku wschodniego przed 1989 roku. Choć na nowo redagowano podręczniki historii, zmieniano nazwy placów i ulic, patronów różnorakich instytucji, burzono dawne i budowane nowe pomniki, polityka zamazywania pamięci nie doprowadziła do trwałego zapomnienia o wydarzeniach ważnych dla opozycyjnie nastawionych do ówczesnej władzy grup społecznych. Podobnie rzecz się miała w przypadku algierskich imigrantów we Francji. Paradoksalnie, konsekwencją polityki historycznej władz francuskich było wzmocnienie się algierskiej wspólnoty pamięci o kolonializmie i o wojnie w Algierii. Wspólnotę taką, według Lecha M. Nijakowskie- 
go (2008: 145-148), tworzą ludzie współdzielący pamięć o określonym wydarzeniu - jego osobiści uczestnicy, ich potomkowie oraz osoby, dla których tożsamości jest ono ważne.

Przykładem możliwości organizacyjnych i mobilizacyjnych algierskiej wspólnoty pamięci jest zorganizowanie w 2011 roku, w 50. rocznicę tzw. masakry paryskiej z 17 października 1961 roku, wielotysięcznej manifestacji, której głównym postulatem było oficjalne uznanie przez władze państwowe odpowiedzialności za skutki tego tragicznego wydarzenia. Uczestnicy pochodu - przede wszystkim Algierczycy, ale i nielegalni imigranci (les sans-papiers), działacze mniejszych partii lewicowych, przedstawiciele organizacji studenckich i związków zawodowych, a także osoby prezentujące transparent z napisem EUROPALESTINE - trzymali tabliczki z nazwiskami osób, które zginęły lub zaginęły w czasie upamiętnianych wydarzeń. Rozdawano również ulotki informacyjne wraz z reprodukcją ikonicznej już fotografii, symbolizującej opór mniejszości algierskiej wobec francuskiej polityki zapomnienia (Lemire, Potin 2002) - na rozdawanych przechodniom ulotkach widniała reprodukcja fotografii przedstawiającej jeden z mostów nad Sekwaną, na którym kilka dni po masakrze ktoś napisał: „Tutaj topi się Algierczyków” (/ci on noie les Algériens). Hasło to wykorzystywano też na innych ulotkach, na których przywoływano także symbole arabskie i muzułmańskie (litera „c" W wyrazie oznaczającym październik zastąpiona została przez półksiężyc).

Poczynione przez władze Paryża gesty - świadczące o skuteczności obranych przez mniejszość algierską strategii podtrzymywania i odbudowywania pamięci - takie jak otwarcie, pod wpływem silnych nacisków, archiwum prefektury paryskiej policji (Liauzu 2005: 104), umieszczenie w pobliżu mostu Saint-Michèle tablicy przypominającej o 17 paździer-

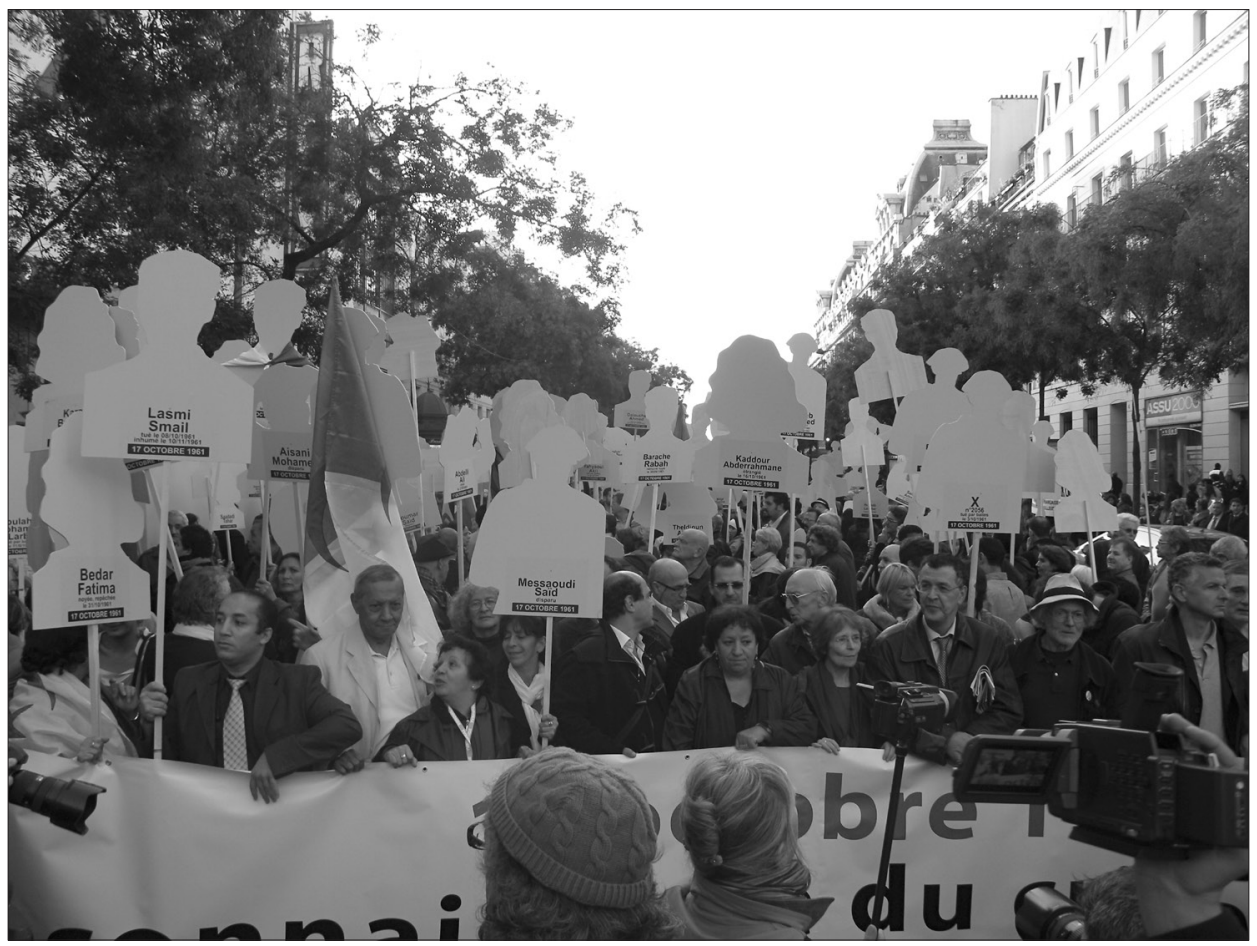

Uczestnicy manifestacji z 17 października 2011 roku, zorganizowanej w 50. rocznice tzw. masakry paryskiej (fot. J. Kubera) 
nika 1961 roku czy nadanie imienia Maurice'a Audina (matematyk i działacz komunistyczny zabity przez żołnierzy francuskich w czasie batalii o Algier) jednemu z paryskich placów (Liauzu 2005: 102), można uznać za próbę poradzenia sobie z sytuacją konfliktową, jaka narosła wokół tragicznego wydarzenia, o którym przez lata opinia publiczna nie chciała pamiętać. Jednak - abstrahując nawet od ważnych szczegółów, takich jak umiejscowienie wspomnianej tablicy pamiątkowej na jednym z brzegów, blisko podłoża i obok znacznie większej i bardziej rzucającej się w oczy tablicy z nazwą mostu - sam fakt uczczenia pamięci Algierczyków, którzy zginęli w trakcie tzw. masakry paryskiej, z pewnością nie wystarczy tym, którzy uważają się za ich spadkobierców. Niebezpieczeństwo „oddelegowania przymusu pamiętania na pomniki czy tablice informacyjne" istniejące w przypadku strategii upamiętniania grup mniejszościowych, o którym pisze Joanna Erbel (2011: 89) wydaje się tutaj nie zachodzić. Rozmowy z uczestnikami ubiegłorocznej manifestacji ukazywały emocjonalny charakter ich pamięci o wydarzeniach 17 października 1961 roku i o wojnie algierskiej, potwierdzając, że konflikt zakończony oficjalnie w 1962 roku, będzie trwać dopóty, dopóki nie zmieni się - chroniąca amnestiami dawnych, w oczach Algierczyków, przestępców - oficjalna polityka państwa wobec sposobów jego upamiętniania.

Podczas manifestacji zorganizowanej w 50. rocznicę tzw. masakry paryskiej postulowano również ogłoszenie 17 października narodowym dniem imigracji (notabene, w Algierii dzień ten obchodzony jest jako dzień emigracji [Lemire, Potin 2002]), co dowodzi szczególnego znaczenia mniejszości algierskiej we francuskiej mozaice etnicznej (przypomnijmy, że wraz z Algierczykami w pochodzie wzięły udział także inne grupy etniczne). Podobnie jak w czasie ubiegłorocznej manifestacji, Algierczycy znajdują się dziś, symbolicznie, z przodu pozostałych imigrantów w Heksagonie, często mówiąc również w ich imieniu. Znajduje to swoje oparcie w wyjątkowej historii relacji pomiędzy Algierczykami a Francuzami (Stora 2007: 13), która mimo upływu kolejnych lat czyni z imigrantów algierskich głównych adwersarzy w dyskusji o przeszłości kolonialnej Francji i jej współczesnej polityce integracyjnej.

WOJNA BEZ KOŃCA?

Wydaje się, że szansą na rozwiązanie sporu o pamięć społeczną na temat wojny w Algierii może być jedynie zmiana charakteru obecnie prowadzonej debaty. Oznacza to, po pierwsze, uznanie, że rozmowy prowadzą obywatele tego samego państwa, którzy posiadają takie samo prawo do wpływania na kształt jego polityki. Zarówno dla potomków algierskich imigrantów, jak i dla pozostałych Francuzów wiązałoby się to z podkreśleniem ważności republikańskiej definicji narodu, która opiera się na przynależności do pewnego porządku prawnego, pomijając różnice etniczne, religijne czy regionalne. Zaakceptowanie przynależności do tego samego organizmu państwowego i, w definicji republikańskiej, narodowego - trudne dla obu stron, ale odpowiadające rzeczywistości prawnej - mogłoby być pierwszym krokiem w dyskusji nad wspólnymi doświadczeniami. Po drugie, ważne jest prowadzenie takiej debaty nad przeszłością, która nie odwoływałaby się do obowiązujących współcześnie sądów normatywnych czyniących ją anachroniczną. Próbując mówić o niegdysiejszych decyzjach, musimy być świadomi, że osoby, które je podejmowały nie zawsze miały pełną wiedzę na temat ich dalekosiężnych, dziś dla nas oczywistych, konsekwencji (Etienne 2006: 163). Po trzecie, konieczne jest zrezygnowanie z „hiperinflacji językowej” (Etienne 2006: 153), która przejawia się w stosowaniu kwanty- 
fikatorów ogólnych nieuwzględniających zróżnicowania postaw różnych zbiorowości zaangażowanych w wojnę algierską. Wiąże się to z uwzględnieniem, że tak po jednej, jak i po drugiej stronie konfliktu znajdowały się jego ofiary. Po czwarte, konstruktywne debatowanie o wydarzeniach z lat 1954-1962 wymaga nieprzenoszenia sądów o ich kolektywnych aktorach na drugie, trzecie i kolejne pokolenia. Próbując umiejscowić się we współczesnym społeczeństwie francuskim, którego są dziś częścią, dzieci i wnuki imigrantów algierskich, repatriantów czy harkis, nie mogą tak często, jak obecnie (Stora 2007: 65-66), zwracać się ku przeszłości. Jeśli dla pozostałych Francuzów pewnym wyzwaniem jest wyzbycie się - wynikającego ze stereotypu - strachu przed imigrantami z krajów Maghrebu, to potomkowie imigrantów algierskich muszą zdefiniować swoje, a nie odziedziczone, postrzeganie Francji. Jak pisze urodzony w Algierii i podtrzymujący relacje z rodziną w tym kraju Achour Ouamara (1997: 35), przypominanie o wojnie w Algierii służy czasami nie tyle podtrzymywaniu pamięci, ile wskrzeszaniu nienawiści, okrywającej strach przed Francją i Francuzami. Jego zdaniem, Francja pełni w tych przypadkach funkcję, znanej z psychoanalizy, figury ojca, którego, aby żyć w harmonii z sobą i z bliskimi, trzeba symbolicznie zabić (Ouamara 1997: 38). Stąd zdaniem tego socjologia, każde mea culpa, na jakie decydują się niekiedy Francuzi, uznawane jest za niewystarczające: „Jeśli Francja by nie istniała, trzeba by ją wymyślić" (Ouamara 1997: 38, 53). Wydaje się, że podobnie można by powiedzieć o niektórych Francuzach, dla których przyznanie się do przestępstw okresu wojennego i błędów kolonializmu byłoby poniżeniem Francji niemal równoznacznym z tym, jakiego, ich zdaniem, doznała ich ojczyzna, godząc się na postulaty algierskich ugrupowań politycznych i militarnych, którym odmawiali nie tylko legitymacji społecznej, ale które uważali również, z powodu stosowania metod wykraczających za sfere dyplomacji, za ugrupowania przestępcze.

Wnioskiem, jaki płynie zarówno dla potomków imigrantów algierskich, jak i dla potomków innych zbiorowości pamiętających o wojnie w Algierii, jest konieczność wspólnego myślenia o przyszłości, dla którego przeszłość byłaby jedną z wielu znanych lekcji historii, jakich nie warto już ponownie przerabiać. W praktyce oznacza to zrezygnowanie zarówno z polityki zapomnienia, która wiedzę o przeszłości traktuje jak balast, jak i z takich strategii przypominania, które sprawiają, że przeszłość przesłania teraźniejszość, uniemożliwiając funkcjonowanie i porozumiewanie się ważnych grup społecznych. Pomiędzy ciągłym przypominaniem a całkowitym zapomnieniem odnaleźć można przestrzeń, w której przeszłość pozostaje przeszłością, a nie teraźniejszością.

\section{LITERATURA}

Appadurai Arjun. 2009. Strach przed mniejszościami. Esej o geografii gniewu, tłum. Marta Bucholc. Warszawa: Wydawnictwo Naukowe PWN.

Attias-Donfut Claudine, Wolff François-Charles. 2009. Le destin des enfants d'immigrés. Un désenchaînement des générations. Paris: Stock.

Bantigny Ludivine. 2007. Temps, âge et génération à l'épreuve de la guerre: La mémoire, I'histoire, l'oubli des appelés en Algérie. "Revue historique”, nr 2007/1.

Belaskri Yahia. 2007. De l'immigré algérien au franco-maghrébin. W: Belaskri Yahia (red.), Les Franco-Maghrébins et la République. Paris: Agence de Promotion des Cultures et du voyage. 
Bilan du premier tour de l'élection présidentielle de 2002. W: Strona internetowa francuskiej Rady Konstytucyjnej - Conseil Constitutionnel, http://www.conseil-constitutionnel.fr/conseil-constitutionnel/root/bank/pdf/conseil-constitutionnel-16535.pdf (data pobrania: 3 marca 2012).

Blanchard Pascal, Veyrat-Masson Isabelle. 2009. Les guerres de mémoires: un objet d'étude? , "Tracés. Revue de Sciences humaines”, nr 9/2009.

Bruckner Pascal. 2006. La tyrannie de la pénitence. Essai sur le masochisme occidental. Paris: Grasset.

Camilleri Carmel. 1990. Positionnement identitaire chez l'adolescent maghrébin en France. W: Kridis Noureddine (red.), Adolescence et identité. Marseille: Hommes et perspectives.

Chavanon Olivier. 2001. Les drôles de Nègres de l'entre deux-guerres: immigrants italiens, espagnols, polonais à Lyon. W: Savoie Etienne (red.), Les noms que l'on se donne. Processus identitaire, expérience commune, inscription publique. Paris: L'Harmattan.

Chemin Ariane. 2011. La longue histoire d'un massacre oublié. "Le Monde”, 17.10.2011. http://www.presseurop.eu/fr/content/article/1065771-la-longue-histoire-d-un-massacre -oublie (data pobrania: 23 kwietnia 2012).

Dobiecki Grzegorz. 2012. Historia, histeria, hipokryzja. „Wprost”, 5.02.2012.

Erbel Joanna. 2011. W strone heterogenicznej metropolii. Sztuka publiczna Warszawy a mniejszości. W: Jałowiecki Bohdan, Sekuła Elżbieta Anna (red.), Metropolie mniejszości. Mniejszości w metropoliach. Warszawa: Wydawnictwo Naukowe Scholar.

Etienne Bruno. 2006. Lois mémorielles ou abus de mémoire. "La pensée de midi", nr 3/2006.

Fabbiano Giulia. 2009. Mémoires familiales en question. „Projet”, nr 4/2009.

Gonzales Jean-Jacques. 2007. Introduction. W: Belaskri Yahia (red.), Les Franco-Maghrébins et la République. Paris: Agence de Promotion des Cultures et du voyage.

Intentions de vote à l'élection présidentelle. 2012. Strona internetowa TNS Sofres, Sopra Group, http://www.tns-sofres.com/_assets/files/2012.02.28-iv7.pdf (data pobrania: 3 marca 2012).

Kwiatkowski Piotr Tadeusz. 2010. I/ wojna światowa jako doświadczenie narodowe. W: Kwiatkowski Piotr Tadeusz, Nijakowski Lech M., Szacka Barbara, Szpociński Andrzej. Między codziennością a wielką historią. Druga wojna światowa w pamięci zbiorowej społeczeństwa polskiego. Gdańsk-Warszawa: Wydawnictwo Naukowe Scholar.

Kwiatkowski Piotr Tadeusz. 2009. Społeczne tworzenie niepamięci. W: Nijakowski Lech M. (red.), Etniczność, pamięć, asymilacja. Warszawa: Wydawnictwo Sejmowe.

Le Cour Grandmaison Olivier. 2006. Passé colonial, histoire et "guerre des mémoires". "Multitudes", nr 3/2006.

Lemire Vincent, Potin Yann. 2002. "Ici on noie les Algériens". Fabriques documentaires, avatars politiques et mémoires partagées d'une icône militante (1961-2001). "Genèses", nr 4/2002.

Liazu Claude. 2005. Les historiens saisis par les guerres de mémoires coloniales. "Revue d'histoire moderne et contemporaine", nr 5/2005.

Monneret Jean. 2008. La guerre d'Algérie en trente-cinq questions. Paris: L'Harmattan.

Niessen Jan, Huddleston Thomas, Citron Laura. 2007. Indeks polityki integracji migrantów. Bruxelles: British Council/Migration Policy Group.

Nijakowski Lech M. 2008. Polska polityka pamięci. Esej socjologiczny. Warszawa: Wydawnictwa Akademickie i Profesjonalne. 
Ouamara Achour. 1997. Oublier la France. Confession d'un Algérien. Paris: Éditions de I'Aube.

Stankiewicz Wojciech. 2011. Prawa imigrantów a wysiedlanie Romów we Francji i reakcja Unii Europejskiej. „Sprawy Narodowościowe. Seria nowa”, nr 2/2011.

Stora Benjamin. 2007. La guerre des mémoires. La France face à son passé colonial (entretiens avec Thierry Leclère). Paris: Éditions de l'Aube.

Stora Benjamin. 2008. Les guerres sans fin. Un historien, la France et l'Algérie. Paris: Stock.

Thenault Sylvie. 2004. Travailler sur la guerre d'indépendance algérienne: Bilan d'une expérience historienne. „Afrique \& histoire”, nr 1/2004.

Viet Vincent. 2002. Histoire de Français venus d'ailleurs de 1850 à nos jours. Paris: Perrin.

\author{
THE MEMORY OF WAR, THE WAR OF MEMORY. \\ SOCIAL MEMORY OF THE WAR IN ALGERIA IN RELATIONS \\ BETWEEN FRANCE AND THE ALGERIAN IMMIGRANTS
}

\begin{abstract}
Summary
The year 2012 marks the 50th anniversary of the official end of the Algerian war. The memory of this conflict and other events in France which accompanied it is still alive in the French society. After many years of oblivion and lack of interest from the highest authorities, this conflict once again becomes the subject of great controversy and heated debate. The disputes focus on the four groups: the French born in Algeria, the Algerians cooperating with the French troops during the war, the other Algerian immigrants and, finally, the former military personnel serving in Algeria. Each group has its own perspective of the events, whereas the politicians try to exploit the memory of the war in the ongoing disputes concerning the integration of the immigrants and the riots in the suburbs. All of this means that even after 50 years the issue of the Algerian war is still evoking new conflicts.
\end{abstract}

Keywords: Algerians, France, social memory, Algerian War, immigrants 